\title{
From Rights to Interests: The Challenge of Industrial Relations in Vietnam
}

\author{
Simon Clarke \\ University of Warwick, UK \\ Chang-Hee Lee \\ ILO Regional Office for Asia and the Pacific, Thailand \\ Do Quynh Chi \\ Ministry of Labour, Invalids and Social Affairs, Vietnam
}

\begin{abstract}
Since the mid-r99os Vietnam has achieved rapid economic growth based on the attraction of foreign investment within an unchanged political environment. Changing employment relations have presented a major challenge to the rights-based institutional forms of regulation of industrial relations established in the early stages of reform, which have proved slow to adapt to the new circumstances in which disputes are interest-based. The persistence of strikes has led the authorities to pay increasing attention to industrial relations issues, but their approach remains confined within the legalistic framework of the state-socialist era. Trade unions show little inclination or ability to stand up to employers on behalf of their members, while Vietnamese workers show a preference for direct action over representation through bureaucratic industrial relations structures.
\end{abstract}

Contact addresses: Simon Clarke, Department of Sociology, University of Warwick, Coventry CV4 7AL, UK. [Simon.Clarke@warwick.ac.uk]; Chang-Hee Lee, Industrial Relations Specialist, Sub-Regional Office for East Asia, ILO Regional Office for Asia and the Pacific, PO Box 2-349, Rajdamnern, Bangkok Io200, Thailand. [email: chlee@ilo.org]; Do Quynh Chi, International Cooperation Department, Ministry of Labour, Invalids and Social Affairs, 2 Dinh Le Street, Hanoi, Vietnam. [email: doquynhchi79@yahoo.com] 
Previously published accounts of industrial relations developments in Vietnam have focused on the comparison with China, with the emphasis on the latter country. Anita Chan and Irene Nörlund argued that the Vietnamese trade unions have enjoyed more freedom from government control than have the Chinese unions, but this argument was based primarily on a reading of differences between the Chinese and Vietnamese legislation (Chan and Nörlund, I998). Chan and Nörlund pinned high hopes on the future independence of the 'occupational unions', to which we will return later. Ying Zhu and Stephanie Fahey (1999) saw both China and Vietnam as groping towards a 'third way', but distinguished them by pointing to a lower degree of differentiation between management and workers in Vietnam which, they argued, reflects the cultural difference between China's hierarchical values of Confucianism and the Vietnamese emphasis on values of harmony and homogeneity (Zhu, 2002: 130$){ }^{1}$

The articles referred to earlier focused mainly on the legal and institutional provisions for the regulation of labour relations in Vietnam. In this article we want to look more closely at what is happening to labour relations in Vietnam at the level of the workplace. ${ }^{2}$ In particular, we want to look at the reasons for the failure of the Vietnamese industrial relations system effectively to regulate the conflict between employers and employees, which is the inevitable concomitant of the transition to a capitalist market economy. On the one hand, virtually no cases proceed through the conciliation and arbitration structures established to handle industrial disputes (about one case a year in the whole country over the last io years). On the other hand, between 1995 and 2005 there had been 978 recorded strikes, not one of which had been called according to the provisions laid down for a strike to be recognized as legal. These issues came to a head with a massive wave of strikes in early 2006 , in which I40,000 workers demanded wage increases in more than I 50 strikes.

\section{The Transition to a Market Economy in Vietnam}

The Vietnamese state socialist system proved unequal to the task of economic recovery after the American War and a new course, 'doi moi' (renovation), was adopted in December 1986. The legalization of private enterprise resulted in a rapid growth of small businesses, whose economic effects were initially felt primarily in agriculture and the service sector, while around $\mathrm{Im}$ jobs were shed in the state sector as tight budget constraints were imposed, leading to an upsurge of unemployment. Following the lifting of the US economic embargo in I994, Vietnam showed itself to be a very attractive outlet for foreign direct investment (FDI) for export processing, which led to a rapid growth of the industrial sector from the mid-I 990 s. The 1998 Asian financial crisis initially led to production cutbacks and layoffs in the export sector, but this inflicted only a minor 
dent on the growth record. Since I993, more than US\$r bn a year has poured in to Vietnam as FDI, Vietnamese GDP has grown at an average 7.2 percent per annum (8.4 percent in 2005) and manufacturing industry has been growing at more than I I percent per annum, with growth being even more rapid since 2000 (World Bank, 2004a,b).

Despite rapid urban and industrial growth, 74 percent of the $82 \mathrm{~m}$ population still lives in rural areas and the vast majority of the population still works in low wage self- and household employment. ${ }^{3}$ About io percent of the labour force is employed directly by the state, with just under half of enterprise employees, who make up I 2 percent of the labour force, working in the state sector, 6 percent working in 'equitised' former state enterprises, 27 percent in the domestically owned private sector and 15 percent in the foreign invested sector, which in 2003 accounted for 36 percent of industrial output and 50 percent of export revenue (Vietnam News Service, I3 Feb 2004). Forty-seven percent of the labour force employed in enterprises works in manufacturing industry. Urban unemployment is around 6 percent, with rural unemployment and underemployment being considerably higher. However, it is not proving easy to mobilize the rural reserve army of labour at wages that investors are willing to pay.

Politically Vietnam is very centralized, local bodies only having significant power in Hanoi and Ho Chi Minh City (HCMC) and, although neo-liberal 'reformers' are in the ascendant, 'conservative' elements in the regime remain strong, so the government has had to maintain some commitment to the protection of workers' rights. Reform of state-owned enterprises (SOEs) has proceeded very cautiously since the mid-r99os, the trade unions remain politically powerful, and the government has included a strong anti-poverty dimension in its economic policies, to impressive effect.

\section{The Institutional Framework for Industrial Relations in Vietnam}

\section{The Legal Framework}

With market reforms the state enterprise became a self-governing unit, responsible for covering its own costs, for hiring and firing its own employees and for determining its own levels of wages and employment, although the state still dictates wage scales in SOEs. Market reform saw a rapid growth of domestic private (DPEs) and foreign-invested enterprises (FIEs) over which the state had limited direct influence.

Between I990 and I994 a new legal and institutional framework was put in place for the regulation of employment relations in the new conditions of a market economy (for a review, see Li et al., 2003), a process that was completed with the revision of the Labour Code in 2002, which finally shifted responsibility for the regulation of the employment relation onto employers and employees, with the state retaining only a residual role. The new system is 
based on the definition and enforcement of the rights of employees as defined by the law, their contracts of employment and collective agreements, rather than on the explicit recognition and regulation of the conflicting interests of employers and employees. This approach defines the role of the trade unions as being to represent the rights, rather than the interests, of their members, with a Labour Code that offers a high degree of protection to Vietnamese workers and a trade union law that encourages trade union organization and the negotiation of legally binding collective agreements.

The introduction of a Trade Union Law in 1990 followed the declaration of a degree of independence of the trade unions from the Party-state at their 1988 Congress, at which they changed their name from the Vietnam Federation of Trade Unions (VFTU) to the Vietnam General Confederation of Labour (VGCL), expressing their intention to broaden and democratize their activity and to extend their organization beyond the state sector (Chan and Nörlund, I998: I 84). Under the trade union law, it is only necessary for a trade union to 'inform the government body or organisation concerned in order that official relations may be established' (Article I.2), which Chan and Nörlund read to imply that 'more autonomous union branches may emerge' (Chan and Nörlund, I998: I 86), although all of our Vietnamese informants were clear that in practice a trade union could only be established legally under the VGCL umbrella. Article 2.I defines the responsibility of the trade union to 'represent and protect the rights and legitimate interests of the workers' and the trade union is responsible for monitoring the observance of relevant laws (Article 9.I) and for representing workers in the negotiation of collective agreements (Article I I.I) and in negotiations to resolve labour disputes (Article I I.3), but the Law also makes the trade union 'responsible for liaising with the State in order to increase production, create jobs and improve the standard of living of workers'. Other articles similarly reaffirm the traditional participation of the trade union, 'under the leadership of the Vietnamese Communist Party' (Article I.I), in various aspects of enterprise and State management and reaffirm its responsibility for organizing production competitions and sporting, recreational, tourist and cultural activities (Socialist Republic of Vietnam, I990).

In the light of the new Trade Union Law, VGCL adopted a new constitution in I 993 that, among other things, provided for the organization of trade unions on a sectoral basis that 'are not necessarily arranged in accordance with the administrative organisation of the state' (Article 22.I cited in Chan and Nörlund, I998:I87), although in practice it seems that they are so organized (Zhu and Fahey, I999: I 84). For example, in 1997 five industrial unions were merged into the National Union of Industrial Workers as a result of the reorganization of their supervising ministries. However, sectoral unions are more distanced from the political structure in that they are under the supervision of the relevant line ministry (one of our respondents referred to his superior sectoral union as the 'ministry union'), while the district union organizations are under the immediate supervision of the local People's Committee and Party organization. ${ }^{4}$ 
A new Labour Code was adopted in 1994 and amended in 2002 (Socialist Republic of Vietnam, I994, 2002). The Labour Code provides a framework for the regulation of employment relations on the basis of individual labour contracts and collective agreements. The Labour Code provides a strong basis for the protection of employees from overexploitation in specifying the length of rest and meal breaks, the maximum length of the working week as six eighthour days, with a limit on the hours of overtime that can be worked, establishing a minimum wage and specifying the premia to be paid for overtime, night and holiday working and specifying social insurance contributions and benefits. The minimum wage is differentiated by region and sector, with the minimum wage for FIEs being more than double that to be paid by domestic employers. The Labour Code also severely restricts the ability of the employer to impose fines on employees or to dismiss them; makes special provision for female and young workers; provides relatively generous redundancy payments; gives the trade union considerable rights to consultation, in addition to its role in collective bargaining, and requires the employer to provide facilities, time for union work and employment protection for trade union officers. Finally, the Labour Code provides a system for the resolution of individual and collective labour disputes through conciliation and arbitration and gives employees the right to strike in the case of a collective labour dispute once these procedures have been exhausted, provided the strike decision is made by the trade union and endorsed by a majority of employees. Employees in certain essential industries and enterprises are prohibited from striking and the Prime Minister can suspend or end a strike if it 'is considered to be detrimental to the national economy or public safety' (Article I75).

The 2002 amendment of the Labour Code specified more precisely the admissible forms of labour contract, increased the rates of overtime pay and required all employers to facilitate the establishment of a trade union organization within six months. The local Departments of Labour, Invalids and Social Affairs (DOLISA) offices register collective agreements, internal regulations, wage scales and wage tables but no longer have the responsibility for approving the collective agreement, intervening only when it violates the law, for which purpose they now explicitly have the 'power to declare a collective agreement to be partially or wholly invalid' (Article 48.3).

Responsibility for monitoring the enforcement of labour legislation is in principle divided between the Ministry of Labour, Invalids and Social Affairs (MOLISA) and VGCL, but in practice the main responsibility falls to MOLISA, since VGCL has almost no leverage outside the state-owned sector. Even senior VGCL officials recognize that the priorities of increasing investment and employment inhibit such enforcement, especially in the Enterprise and Industrial Zones. The sanctions on employers who violate the Labour Code are derisory, but DOLISA or VGCL can threaten to refer an employer to the People's Committee or the relevant Ministry and the latter can make life very difficult for an employer, in the last resort even revoking their investment licences, and this threat is much more effective than the threat 
of judicial sanctions. However, the main emphasis is on training and educating employers, especially foreign employers, in their legal obligations, and using persuasion in the event of violations, so that it is very rare for sanctions to be imposed on employers who violate the law.

Every enterprise should be inspected at least once a year, but MOLISA has only 350 inspectors and VGCL has Ioo inspectors to check on nearly 100,000 enterprises. In Hanoi DOLISA there are I I inspectors responsible for 700 state enterprises, 600 foreign-invested enterprises and over 20,000 private enterprises. HCMC DOLISA has five inspectors for more than 30,000 enterprises. DOLISA introduced regular labour inspections in 1997 , but abandoned the practice in 2000 (Tan, 2005), although they reintroduced them in 2005, HCMC DOLISA finding that I 4 out of I 6 enterprises inspected in the ExportProcessing Zone (EPZ) had very poor working conditions and violated the labour law. DOLISA considered that the Zone trade union, which had failed to enforce the law, was too pro-company. There are no statistics on the number of legal violations uncovered by the labour inspectors, but it is unlikely that the inspectors will have time to make many routine inspections, once they have dealt with cases of industrial accidents and complaints which have given rise to work stoppages. This means that responsibility for monitoring the enforcement of labour legislation, as for the negotiation and enforcement of collective agreements, in practice falls to the enterprise and district level trade union organizations.

\section{The Vietnamese Trade Unions}

In the state socialist system all enterprises were the property of the state and all their staff, from the general director to the lowliest worker, were state employees, their wages determined according to state wage scales. In the countryside, where the vast majority of the population lived and worked, agriculture was collectivized but traditional land tenure systems also persisted. Virtually all state employees were members of the trade union, which was an integral part of the Party-state apparatus, responsible for encouraging labour motivation, the provision of sporting and cultural facilities and, until I995, for training and the administration of the rudimentary system of social insurance, to finance which the unions received 5 percent of payroll (Zhu and Fahey, I999: I84).

\section{Trade Union Structure and Membership}

At the end of 2003 , VGCL claimed $4.3 \mathrm{~m}$ members, of whom about Im were in the non-state sector, so VGCL organized a little over Io percent of the total working population of Vietnam or about 40 percent of the employed labour force. There was considerable variation in density between sectors, with about 95 percent membership in the public sector, $90 \%$ in state enterprises, about $50 \%$ in the foreign-invested sector and about 30 percent in domestic private enterprises, according to VGCL. Members belonged to 61,500 primary 
organizations, of which 10,500 were non-state. Each primary organization is subordinate to one of 623 district level organizations or 436 local sectoral trade unions, which in turn are subordinate to the 64 provincial federations and 20 central sectoral unions that comprise VGCL (large enterprise unions may be subordinate directly to the relevant provincial or central sectoral union). The sectoral unions organize about one quarter of the total VGCL membership, the largest being the National Union of Industrial Workers with almost half a million members.

The main priority of VGCL is currently a campaign announced at its 2003 Congress to add Im members in the private sector over the next five years, a campaign that has the full support of the Party and relevant state bodies and which is being achieved primarily by bureaucratic methods, reminding employers of their obligations under the Labour Law, rather than on the basis of any active organization and recruitment of private sector employees, although a more active approach to organization in $\mathrm{Ha}$ Tay province was reported as providing a model for a new approach (Lao Dong Daily, I 5 December 2005). By June 2005 VGCL claimed $5.2 \mathrm{~m}$ members, an increase of almost a million in I 8 months, in 82,000 primary organizations with 7000 full-time and 300,000 part-time union officers, to give an overall union density of $\mathrm{I} 2$ percent.

\section{Trade Union Functions}

The Trade Union Law and VGCL Constitution certainly provide for the possibility of the enterprise trade union independently representing the workers' rights and interests, but many circumstances conspire against this. In the first place, traditional mentalities and traditional practices continue to prevail. The trade union was traditionally part of the system of economic and political management, helping management to achieve its production plans by strengthening labour motivation and labour discipline, with particular responsibility for providing social welfare and sporting, cultural and entertainment facilities, and it is still thought of in this way by the vast majority of trade unionists and employees. The protective functions of the trade union were carried out not in the workplace, but through participation in the political system. VGCL, particularly at national level, continues to be oriented primarily to exerting influence within the political system, to secure laws, decrees and regulations which provide for tolerable working conditions for its members. One senior VGCL informant emphasized that VGCL is a central part of the political system of Vietnam, defining its functions as being to represent the rights and interests of workers 'as stipulated in the law and collective agreements' (emphasis added); to contribute to the administration of society by contributing to state administrative agencies; and to provide training, information and education to workers. VGCL is closely integrated into Party-state structures at all levels, its own organization mirroring the structure of the Party-state and its bodies at all levels collaborating closely with the local labour department under the supervision of the relevant Party body 
so that there are no clear dividing lines between the responsibilities of Party, trade union and state bodies.

Certainly, VGCL has continued to be a very effective lobbyist for the interests of labour in the political system and remains politically powerful, with its Chairperson having ministerial rank, while employers' representation is only in the early stages of development. However, VGCL is much less concerned to ensure that there are mechanisms in place to ensure the enforcement of labour legislation, let alone to help its primary organizations to bargain effectively with the employers. There was no significant discussion of collective bargaining at the last VGCL Congress in 2003. VGCL does not have a collective agreement or industrial relations department, responsibility for industrial relations being split between the Legal Department and the Department of Economic and Social Policy, ${ }^{5}$ while it only provides training in collective bargaining as part of more general training, using translations of inappropriate foreign training materials. There are no specialized materials for training in wage negotiation. ${ }^{6}$ A senior VGCL official estimated that IO-I 5 percent of union officers receive training each year, but priority is given to higher level officials on the grounds that their tenure is more stable, since local and enterprise union leaders are re-elected every two years. Very few of the trade union presidents in the enterprises we visited had received any training in collective bargaining and they received very little advice or support in carrying out their trade union functions in the workplace. Workplace trade union organizations are very much left to their own devices.

\section{Trade Unions and the Communist Party}

According to the law and its own constitution, VGCL operates under the leadership of the Communist Party. At the highest levels the interpenetration of Party and trade union apparatuses is very close. The Chairperson of VGCL must be a member of the Central Committee of the Communist Party, and all representatives at regional and central level should have a Party position, so nominations for these positions are controlled by the Party. In SOEs the trade union and the Party organization continue to work together with the Youth League and enterprise director in the 'group of four' and the trade union chair in an SOE should be a Party member, although nowadays the Party no longer nominates the chair, only 'makes suggestions'. This situation is likely to persist in equitized SOEs and in some joint ventures, but in non-state enterprises there may be no Party organization, or the Party organization may be moribund. Generally, at the lowest levels of trade union organization (workshop, branch) there are no corresponding Party bodies.

The subordination of the trade union to the Party represents the subordination of the immediate interests of trade union members to the wider social, economic and political goals of the Party, and at the enterprise level these generally coincide with the interests of management. One of our respondents described the role of the Party organization in the enterprise as being ' $\mathrm{HR}$ 
development ... how to get loyalty and improve the skills of workers, Party cells encourage mass organisations to achieve the targets set by the General Director and how to save on materials etc.' (cf. Wang, 2005).

The Party is hardly likely to provide a restraining hand on enterprise management in state and former state enterprises: in three of the four equitized SOEs that we visited the General Director was the Party Secretary, while in the fourth the Party Secretary was the Deputy General Director in charge of HR, which we were told is the more normal situation in an SOE. In joint ventures the situation is rather different, since the Party organization is responsible for keeping an eye on the foreign managers and, if not representing the interests of the Vietnamese workers, at least making sure that an overt conflict situation does not arise (Dixon, 2000: 285). Thus, one of the joint ventures that we visited had a very active and effective trade union chair who clearly enjoyed the support of his Party secretary.

There was no active Party organization in any of the private and foreigninvested enterprises that we visited. There is currently some discussion about extending Party organization to such enterprises by law. A senior VGCL official commented that this 'would be good for the employers and employees because they have the same goal - operation of the business and the interests of workers. The Party would not intervene in management and the Party will encourage the union to work with the employers'.

\section{Trade Unions in the Enterprise}

In SOEs and former SOEs it would seem that the enterprise trade union continues to function much as it did in the past. Although the trade union nominally has the function of negotiating terms and conditions of employment that were formerly dictated from above, the government still stipulates the wage scales and wage tables for SOEs (and those of all other enterprises have to be registered with the relevant branch of MOLISA).

The four equitized SOEs that we visited had retained the state-socialist authoritarian-paternalist system of management more or less intact. In one of the four the trade union was fully integrated into the management structure as part of the 'group of four', organized in a Social and Political Department headed by the Deputy Party Secretary. In two large corporations the trade union president was a very experienced full-time professional trade unionist, in the other two companies the trade union president was a senior manager (HR manager and head of the biggest production division respectively). The trade union can be very effective in such circumstances, but as an instrument of employer paternalism rather than as a representative of the employees. All four companies were prosperous enough to pay relatively good wages and the collective agreements provided some benefits in addition to those prescribed by law, such as payment for weddings and funerals and Tet (New Year) bonuses, but in all four cases the agreement was dictated by management and there was little or no consultation with employees in drafting it. In one case, although the 
collective agreement provided for the payment of benefits for weddings and funerals, it turned out that these benefits were actually paid out of trade union funds. At the same enterprise, the collective agreement was formally approved by the workers at the annual shareholders' meeting 'to save time'. All four enterprises have conciliation councils, but not one had ever received a single dispute to mediate, nor had any of the four ever had a strike.

The conception of the role of the enterprise trade union in the non-state sector promoted by the authorities is of the trade union as the partner of the employer, mediating between employer and employees, rather than as the representative of the employees in opposition to the employer. Employers are encouraged to establish trade union organizations and to negotiate collective agreements in the interests of good industrial relations. An effective trade union organization can communicate the aspirations and grievances of the employees to the employer and can explain the concerns and difficulties of the employer to the employees. This role is considered to be particularly important in FIEs, where the Vietnamese workforce is likely to be distrustful of the foreign management and the foreign management to have a limited understanding of Vietnamese traditions and culture.

In private and foreign-invested enterprises a new trade union branch is typically set up at the instigation of the relevant VGCL superior organization, which appoints a temporary president and sets up a provisional standing committee through agreement with the employer, with elections to these positions to follow a year later. Needless to say, the nominated president is usually a manager, often the human resources manager of the company. 'The provincial union approaches the employer and asks for access, if they approached workers directly this would infringe the rights of the employer' (senior VGCL official). If the employer does not want to set up a trade union, even though he is legally required to do so within six months of establishment, then it neither seems that there is any pressure on him to do so, nor is there any sanction prescribed by the law for failure to do so (the only sanction is for obstructing the process). Joint ventures are in something of an intermediate position, because they may inherit a trade union organization from the Vietnamese joint-venture partner or establish a trade union on the advice of the partner. In this case the trade union will have the possibility of enjoying some independence from the foreign manager, particularly if it has the support of a Party cell.

In the EPZs and Industrial Zones (IZs), where many of the foreign-owned companies are located, the Labour Department of the Zone Management Board often plays an active role in setting up new trade union branches, with a view to establishing a trade union organization as a mediator that can 'represent the workers but also help the employer'. Although the representatives of the Labour Departments recognize that trade unions do not do much to prevent strikes from happening, they do find that it is much easier to settle a strike in an enterprise with a trade union. The Labour Department tends to combine state and trade union functions, since the officers of the Labour Department tend also to be senior trade union officers (the Director of the 
Labour Department in the Hanoi Zone Administration is also the head of the zone trade union organization, to which all the enterprise unions report, while the Labour Department Director in HCMC is the former head, now the deputy head, of the zone union, the new head being a VGCL full timer). Thus the enterprise trade unions in the Zones are closely integrated into the system of state monitoring of labour relations.

Vietnam has a strong and long-standing tradition of workplace democracy, with the managers of state enterprises and public sector organizations having to face a vote of confidence at a general meeting every year. In principle the trade unions are very democratic at enterprise level, but the lack of supervision and support from higher union bodies makes it very easy for management to subvert the democratic process (Wang, 2005). Although elections are often contested, we did not find any cases of nominees of the existing standing committee being defeated, although some withdrew before the final ballot. In keeping with the predominant character of the unions, their enterprise standing committees are dominated by line managers and white-collar workers - fewer than one in five committee members in the enterprises that we visited were production workers. Most of the trade union presidents we interviewed had accepted nomination to their positions reluctantly, sometimes under pressure from the employer, and several informants commented on the difficulty of finding people to take up trade union positions.

There is a very strong influence of management over the union in FIEs, so it is common for the HR manager to be the trade union president in such enterprises. The appointment of managers as trade union presidents is a contentious issue within VGCL, some arguing that a clear separation between employer and employee is required, while others insist that there are advantages for the trade union in being led by a manager who has more knowledge and capacity.

The union membership fee is one percent of salary paid by check-off. In principle 50 percent stays with the local enterprise union, although in practice they often keep it all. Except in the FDI sector, the employer also pays 2 percent of the wage, of which 70 percent should go to the local union, 30 percent to the higher level. This is notionally to provide wedding and funeral benefits, to organize production competitions and to pay for cultural and sporting activities, which indeed are the principal items of union expenditure. The government provides VGCL with sponsorship to subsidize trade unions in the FDI sector, where the employer does not pay, although the money is transferred only sporadically.

In principle, in enterprises with more than 500 employees there should be one or two full-time officials appointed and paid by the higher union, but in practice VGCL does not have the funds to cover this, so many enterprises do not have any full-time union staff and in others full-time officers are usually paid by the employer. In HCMC there are about 200 full-time unionists at the enterprise level paid by VGCL, mostly in the FDI sector, and about Ioo more full-time unionists in non-state enterprises paid by the employer. All the full-time trade union presidents in the enterprises that we visited were paid by 
the company. This is not a situation that is conducive to the development of an independent trade union.

Trade union leaders enjoy only weak protection from victimization. According to the law, a trade union president cannot be dismissed without the permission of the higher union body, but in practice, according to several of our informants, employers ignore this restriction and there is a lack of sanctions to stop it. Moreover, there is no requirement on the employer to renew the contract of a trade union activist who is employed on a fixed-term contract.

Once it has been established, the workplace trade union is left largely to its own devices, so there is a lot of variation in performance and a lot depends on the personality of the trade union chair. The higher level unions periodically exhort the enterprise trade unions and instruct them to carry out campaigns, for example to explain the provisions of the labour laws to the employees, but, as noted earlier, seem to provide very little training or support for their everyday trade union activity. In our own limited experience the sectoral unions, or at least the National Union of Industrial Workers, provide more comprehensive training and support for their primary organizations than do the district trade union offices, perhaps because their constituency is more homogeneous.

The main items of spending from the trade union budget in all the enterprises that we visited were presents for weddings and funerals and the organization of sports and entertainments for the workers. When asked why he spends more than half his budget on sports and entertainments, rather than supporting his proper trade union activities, the most active and effective (part-time) trade union president replied that without these activities he would not be able to attract members. The least effective enterprise trade unions did not even have an entertainment programme, but some unions clearly provided a more or less effective channel of communication between employers and employees and in two enterprises the trade union organization did appear to provide effective representation for its members, showing that it is quite possible to improve the quality of trade union primary organizations.

The most important tests of the effectiveness of primary trade union organizations in representing the interests of their members are in the negotiation and monitoring of the collective agreement and in representing their members in individual and collective disputes.

\section{Collective Agreements}

There is no centralized system of reporting the number of collective agreements, so there are no consolidated figures. In 2000, VGCL reported to the International Labour Organization (ILO) that there were collective agreements in ${ }_{5} 6$ percent of SOEs, 36 percent of FIEs and 20 percent of DPEs (Fair Labor Association, 2004). A national VGCL official told us that there were collective agreements in 70 percent of unionized SOEs, under 50 percent of unionized FIEs, and 20 percent of unionized enterprises in the private sector, 
although VGCL in HCMC claimed that there roo percent of state and equitized state enterprises, about 60 percent of FIEs (although only 30 percent of enterprises in EPZs) and 65 percent of unionized private sector enterprises had collective agreements. According to Hanoi DOLISA, in Hanoi about 80 percent of state enterprises and 30 percent of the FIEs have registered collective agreements, while only 5-6 percent of enterprises in the private sector have collective agreements. The absence of collective agreements in unionized enterprises was explained by a number of factors: the weakness of the trade union organization, the reluctance of the employer to undertake obligations that he could not be confident that he could fulfil and the perceived pointlessness of signing a collective agreement that contained no provisions higher than the minimum legal standards.

According to most of our informants in the state and higher level trade union bodies, collective agreements rarely include anything above the minimum legal provisions, ${ }^{7}$ and indeed one local DOLISA official in Hanoi reported that 30 percent even fall short of this. However, in most of the enterprises that we visited the collective agreement included some additional provisions, most typically wedding and funeral benefits. Sometimes there are also meal and transport allowances, picnics and excursions and bonuses to be paid at Tet and for various holidays, which may be at the discretion of management. The collective agreement may also include trade union promises to organize emulation campaigns and to admonish or discipline workers who perform badly. The collective agreement should include agreed wage and bonus scales, but these might be set at the minimum level so that the employer can minimize social insurance payments, severance pay and so on. Sometimes in such cases there will be a separate wage agreement, or the company may simply pay higher rates at its discretion.

In the equitized SOEs that we visited collective bargaining seemed to be a formality, the content of the collective agreement being dictated by management. In one case the first draft of the collective agreement was prepared by the union and it was circulated to employees for suggestions, but in the other three the management simply used the template provided by MOLISA and VGCL, based on that attached to the Labour Code. In two companies the management had established a parallel channel of communication with the employees, one taking the form of an Internet forum, the other a survey of employees, which were used to identify the grievances of employees. ${ }^{8}$ In all four enterprises all decisions about the content of the collective agreement were made by management and its approval by the meeting of employee representatives was a formality.

In the wholly foreign-owned enterprises that we visited the collective agreement had even less significance than in the SOEs. In one company a collective agreement had been signed in 1998 , following a series of strikes, but had not been renegotiated and so had expired. In a second company, in which the trade union president was the newly appointed HR manager, the collective agreement was dictated by the management. In the third company, with a more active 
trade union, the collective agreement only specified the legal minimum terms and conditions, with specific points being negotiated with management on an ad hoc basis, outside the agreement. Management is more willing to make such ad hoc arrangements partly because such agreements are not legally binding, but also because in this case they gave local management more flexibility, since legally binding agreements have to be referred to the foreign owners.

The process of collective bargaining was much more significant in the joint ventures and the domestic private enterprise that we visited. ${ }^{9}$ In all three enterprises regular negotiation over the collective agreement was a trade union initiative, the draft was circulated to all employees for suggestions and there was real bargaining with the employer, including bargaining over wages and bonuses. The employer in each case refused to meet the full demands of the union and the union compromised on the basis of the financial position of the company. Trade union members did not seem to play a very active role in the bargaining process, with few suggestions coming from workers, perhaps because they had confidence in their leadership. In one of the joint ventures workers asked for higher allowances for working in harmful conditions, but the union considered the existing allowances to be sufficient and did not put the demand forward. In the other joint venture annual wage increases are negotiated and incorporated in the collective agreement. In the last negotiation the union asked for a Io percent pay rise and a reduction of the working week from 46 to 44 hours. The management agreed a 5 percent increase and the hours reduction. There have been repeated arguments in this company over the size of bonuses, the determination of which the foreign director insists is a management prerogative. None of the three enterprises has had a strike, but the union is able to play on management's fear of strikes in their negotiations. In the last case, the trade union president reported that the union leaders had to go to the shops on occasion to dissuade workers from stopping work to allow the union to pursue grievances through dialogue.

Apart from providing enterprise trade unions with a model collective agreement, the higher trade union and labour administration bodies provided very little support to enterprise trade unions in their collective bargaining. A senior VGCL officer commented complacently that 'actually there is no wage negotiation, the union monitors individual labour contracts to make sure that they are not worse than the collective agreement ... If they really negotiated, the higher union would have to hire consultants', but a DOLISA officer argued that:

in practice DOLISA makes a greater contribution to collective agreements than VGCL: we check it when we receive it from the enterprise to see if it is legal. We can make suggestions to both sides about the level of mutual agreement. Before the 2002 amendment of the labour code DOLISA played a major role. Since then, we still review and evaluate collective agreements. Enterprises prefer to ask for advice from DOLISA rather than VGCL because we are the specialists ... We suggest that they can negotiate higher than the minimum standards, for example free lunch or wedding and funeral benefits ... [because] it brings benefits for both sides - this advice should be provided by VGCL, but we review the collective agreements. 


\section{Handling of Complaints and Disputes}

There has not been any systematic research into violations of labour law in Vietnamese enterprises ${ }^{10}$ but commentators have generally assumed that publicized violations are the tip of an iceberg and that non-state employers systematically refuse to sign labour contracts; impose excessive and often unpaid overtime and rest-day working; force workers to work in harmful conditions without compensation; fine and dismiss workers illegally; fail to pay social and health insurance contributions; pay wages below the legal minimum and withhold the payment of agreed wages and bonuses. State enterprises are under stricter administrative and Party control, but long delays in the payment of wages and illegal layoffs and dismissals have not been uncommon in state enterprises. In most cases in which strikes occur, subsequent investigation reveals serious and systematic violations of the law by the employer, with the tacit collusion of the trade union where there is a trade union organization. During the r 990 os there was a lot of publicity around working conditions in the factories of Nike subcontractors in Vietnam, but the espousal of 'corporate social responsibility' and the adoption of 'codes of conduct' have supposedly put a stop to such practices. ${ }^{11}$

The enterprise trade union is under conflicting pressures in the face of such violations. On the one hand, it is committed to the success of the enterprise that provides jobs and wages for its members. On the other hand, it is supposed to monitor the observance of labour legislation by the employer and it is required, above all, to maintain industrial peace. In practice this means that the trade union will rarely take the initiative in contesting violations of labour legislation, but it should ensure that any disputes that arise as a result are resolved peacefully through the channels of conciliation and arbitration provided for that purpose.

All enterprises that have a trade union are required to set up a conciliation council with an equal number of representatives of employer and employees. If there is no conciliation council, or if agreement cannot be reached, an individual dispute can be referred to the district conciliator or to the labour court. A collective dispute is referred upwards to the regional Arbitration Council. If the trade union is not satisfied with the result of arbitration it can refer the case to court or, with the support of a majority vote of the labour force, it can legally call a strike.

We were repeatedly told that workers do not have confidence in the neutrality of the conciliation council - employee representatives are often managers and are unlikely to rule against the employer - so very few cases are referred to enterprise conciliation councils and many enterprises have not even bothered to set them up (Zhu and Fahey, 2000: 293). All io enterprises that we visited had a conciliation council, but not one had ever heard a single case. The HCMC Arbitration Council conducted a survey of conciliation at the enterprise and district level (covering 24 districts), which identified 84 collective cases and I I 8 individual cases that had been to conciliation since I995, of 
which 823 had been successfully resolved. The conciliator in District One of HCMC provided conciliation in about Ioo cases in 2003 , mostly in Taiwanese and Korean companies, in which the main issues were wages, social insurance, maternity benefits and the illegal termination of contract. However, many of these cases had not been referred directly by the complainant. As the labour department representative explained to us, they do not wait for a request, they just go down to the enterprise as soon as they hear about a problem, usually when the HR Department or a foreman phones DOLISA and asks for help. This kind of fire-fighting is not officially a function of DOLISA, but they have been asked to take it on by the local People's Committee - 'we don't call it "strike resolution", we call it "initial resolution to ensure social stability in the district".

Collective labour disputes should be referred to the regional Arbitration Council when they cannot be resolved by the enterprise conciliation council. However, because the conciliation council does not work almost no disputes go to arbitration. The Hanoi Arbitration Council has had two cases since it was set up in 1997. Two members of the HCMC Arbitration Council told us independently that it has had only one case since it was set up in 1998 , though neither could remember the details.

All our Vietnamese respondents agreed that the existing system for the resolution of industrial disputes does not work, since the dominant way through which workers pursue their grievances is through wildcat strikes. There have been around Ioo reported wildcat strikes a year in Vietnam since 2000, the majority in the South and two-thirds in FIEs. In addition, many disputes are snuffed out by the timely intervention of the enterprise union or a DOLISA conciliator before they reach the stage of a strike and there are probably many short work stoppages that are not reported because they are not considered to be strikes. Most strikes are short, lasting up to three days, and in the overwhelming majority of cases the employers are persuaded by local officials to pay wages for the duration of the strike and to meet the workers' key demands. The strikes seem to be disciplined and well-organized by their informal leaders and there have been no reports of police action against strikers or their leaders, even when they block roads and access to factories. ${ }^{12}$ Senior officials see the main cause of strikes to lie in the ignorance of employers and workers of the labour law and of the proper procedures for settling disagreements.

The explanation offered by Vietnamese officials for the failure of the dispute resolution system is essentially that the system is too complex and that workers are not aware of the proper procedures, their proposed solution being to simplify the system and to provide more effective training for workers in labour law and disputes procedures. However, this would merely be to rearrange the deckchairs on the deck of the Titanic. The fundamental problem is that Vietnam has sought to transplant a bureaucratic system for the regulation of industrial relations in a state-socialist system, based on rights embodied in government laws and decrees and Party instructions ${ }^{13}$ into the emerging capitalist economy in which employers are no longer directly subordinate to 
the Party-state apparatus, so that there is no longer any adequate mechanism to ensure that those laws, decrees and instructions are respected by employers. The failure of the system is not a failure of understanding on the part of the workers, but the failure of MOLISA adequately to monitor the enforcement of labour legislation and, above all, the failure of VGCL adequately to represent workers in the workplace. Workers are no longer satisfied merely to secure their legal rights, they are interested in securing what they regard as their legitimate interests by the most effective means at their disposal, and the most effective means has proved to be the wildcat strike. The interest-based demands of workers have overflowed the rights-based institutional framework provided for the regulation of industrial relations.

This diagnosis was dramatically confirmed by the strike wave at the end of 2005 , which was initiated by a series of coordinated wildcat strikes led by unidentified informal organizers, involving 30,000 workers demanding a substantial pay increase and improvements in working conditions in seven foreign-owned enterprises in HCMC. Some senior VGCL officials still insist that rights violations are the only reason for disputes and strikes, and VGCL immediately interpreted the workers as demanding an increase in the legal minimum wage 'The HCMC VGCL, together with DOLISA and HEPZA [the Zone administration] explained to workers that the minimum wage must be adjusted by the government. VGCL has already proposed to the Government that it raise the minimum wage starting I January 2006' (Mai Duc Chinh, Vice Chair VGCL HCMC, Lao Dong Daily, 4 January 2006). On the other hand, other local officials are more ready to recognize that an increasing number of disputes arise out of a conflict of interests. Mr Khai, an officer in HCMC VGCL explained in an interview with Lao Dong Daily: 'Workers used to go on strike against legal violations of employers. But now they also walk out for better meals, shorter working hours, higher wages and bonuses' (Vietnam Research Team, 2006: 8).

In the wake of the strikes some VGCL officers continued to insist that the failure was not that of the union, but that of the government. The union had long been pressing for an increase in the legal minimum wage, but the government had prevaricated, postponing the proposed increase to I April in response to an appeal from foreign investors to delay the increase until after the Tet holiday, so provoking the strikes. By contrast, on 5 January, Pham Minh Huan, Director of MOLISA's Wage and Salary Department, in an interview with VnExpress, stated that the conflict was not about where the government had set the minimum wage, but about the actual salary that companies are paying workers. $\mathrm{He}$ emphasized that it is the responsibility of the trade union to negotiate wage increases with employers and the government would respect their decision. He also warned that the minimum wage for FDI enterprises would in future rise more slowly than the lower minimum wage for domestic private enterprises because World Trade Organization (WTO) entry would mean that Vietnam would have to phase out discrimination against foreign employers, the plan being to have a uniform minimum wage by 2008 . Nevertheless, on 6 January 
the Prime Minister issued Decree 03, which increased FDI minimum wages by about 40 percent from I February 2006, and the strikes stopped. However, the increase in the FDI minimum wage provoked a second wave of strikes as non-FDI workers walked out demanding wage increases, with about 20 such strikes in February. Pham Minh Huan announced on 2 I March that the nonFDI minimum wage in Hanoi and HCMC would probably be increased by $5 \circ$ percent later in the year (Thanb Nien Daily, 2 I March 2006).

Meanwhile, in January 2006 the government tabled draft revisions to Chapter I4 of the Labour Code, on dispute settlement procedures, which introduces a distinction between rights-based disputes and interest-based disputes, each with a distinctive settlement procedure, with strikes being permitted only in the case of interest-based disputes. In its comments on the draft, VGCL admitted that union weakness is one of five major causes of strikes (Lao Dong Online, 6 March 2006), while still insisting that legal violations by employers are the major cause of wildcat strikes and pressing the government to strengthen labour inspection. In parallel, MOLISA, VGCL, VCCI and VCA (the latter being the two employers' organizations) were planning to promulgate an 'inter-ministerial action plan on developing sound industrial relations', which proposes a shift of focus from fire-fighting strikes to the prevention of disputes by promoting collective bargaining and social dialogue at the workplace. The HCMC People's Committee also requested VGCL within the next six months to strengthen the capacity of the union at enterprise and district levels and in the Zones. However, there has still been little discussion in VGCL about how to strengthen their workplace organizations, the emphasis being on strengthening the role of provincial level union organizations in strike task-forces and in mediating between workers and employers (at the moment the provincial union can only involve itself in a Zone if requested by the Zone union organization), with a proposal to build up teams of professional union negotiators at provincial level who are capable of supporting their local colleagues in bargaining with employers for better pay and working conditions for workers and a proposal that provincial union organizations should be permitted to negotiate and organize industrial actions on behalf of workplace organizations. There has been no attempt to involve the rank-and-file worker leaders, including strike organizers, in the union because they are considered to be 'bad elements', who are insufficiently educated and lack the status required to negotiate effectively with employers.

The comparison with China is instructive at this point, because China has a very similar institutional framework for the regulation of industrial relations, but in China, the system of conciliation, mediation and arbitration is deluged with appeals from workers and the civil courts are swamped with labour cases, while suppression of strikes has meant that their incidence has, until recently, been extremely low. Several commentators have noted that Vietnamese workers have been more assertive than their Chinese counterparts, because of their solidaristic values (Zhu, 2002: I 30 ) and because of the less restrictive household registration system and independent living arrangements for migrant workers, 
as opposed to the Chinese system of dormitories (Chan and Wang, 2004). The tolerance of strikes and willingness to meet the strikers' demands on the part of the Vietnamese authorities is also in marked contrast to the severe repression of strikers in China.

The big question that arises is whether China and Vietnam provide two alternative patterns for the development of post-socialist industrial relations, or whether they represent two steps on the same path? If the latter, is it China that shows the future to Vietnam, or does Vietnam show China what it has in store? Perhaps as the old generation of socialist leaders in Vietnam gives way to a new generation of pragmatists and Vietnam's accession to WTO increases the pressure of domestic and international competition, the tolerance of strikes will be tested. On the other hand, the indications are that the Vietnamese regime's commitment to the protection of workers is more than rhetorical and it is more likely to accommodate than to repress independent worker organization, while China, like Vietnam, is experiencing growing labour shortages and increasing unrest in the coastal provinces which are the engine of growth. Perhaps Chinese workers will build their own sense of solidarity and self-confidence, and the Chinese government will be forced by escalating protest to follow the Vietnamese example and take a more conciliatory approach to workers' demands. In either case, it seems that the industrial relations system inherited from state socialism is reaching its limits as it is unable to reconcile the conflicts of interest that are an inevitable concomitant of capitalist development.

\section{Conclusion}

As early as I995 an article in the trade union's own newspaper acknowledged that the lack of understanding of labour laws was only one reason for strikes. 'The other reason is the loss of trust and confidence of workers in the official trade unions ... The role of organised trade unions in protecting workers' rights here is diminishing every day and is practically non-existent' (Lan, I995). VGCL recognizes the ineffectiveness of its primary organizations, but is doing little to address the issue, preferring to concentrate on expanding membership while relying on the government and MOLISA to defend its members' interests, as those are embodied in legislation. ${ }^{14}$

Labour activism is always closely related to the labour market situation, which has been changing rapidly in Vietnam as growing labour shortages emerge, even in the North. Labour shortages seem to have emerged first in the demand for experienced managerial and technical workers, partly reflecting the lagging adaptation of the Vietnamese education system to new demands and partly reflecting a demographic structure that is marked by the legacy of the war. Employers have responded to the shortage of such personnel by raising wages, paying loyalty bonuses and even poaching staff from their competitors, while employees have responded not with collective action but with an individualistic exit strategy by moving to better-paid jobs. This pattern may not be repeated with the emerging shortage of ordinary workers. 
The expansion of the foreign-invested sector has mopped up all of the available local workers in the cities around which the industrial zones and EPZs are located, so they are having to rely increasingly on migrant workers from more distant rural areas (according to DOLISA in Binh Duong and Dong Nai, 70-80 percent of workers there are non-resident [Hop, 2004: I]). All of our informants noted that it was becoming increasingly difficult to attract rural workers to the cities because the high cost of living and low wages left them with little money to send back home, their main reason for coming to the city.

Labour turnover has increased, and in some cases reached very high levels, but this is not so much because workers move to better paid jobs elsewhere as because they return to their home villages, particularly after Tet when they do not return from home visits, or leave to take advantage of educational opportunities in the cities. Employers are reluctant to respond to labour market pressures by raising the wages of production workers, particularly when they are competing for export contracts, and generally try to pay no more than the legal minimum wage. ${ }^{15}$ This means that there are fewer opportunities for workers to pursue an exit strategy and that they are more likely to seek higher wages through collective action. Once one group of workers successfully strikes for higher wages, others are likely to follow their example, such contagion being a notable feature of strikes in Vietnam.

Vietnam has established a rights-based system for the regulation of industrial relations in its emerging market economy in which the employment relationship is to be regulated by the labour law, collective agreements and individual contracts and disputes are to be settled on the basis of the rights inscribed in those instruments. However, this system has not been effective in practice. On the one hand, the trade unions and labour administration have been unable to ensure that these rights are respected by employers. On the other hand, Vietnamese workers have not pursued their interests through the institutional channels provided for that purpose. In the past, most strikes have revealed legal violations by the employers and the labour administration has been able to settle the strikes by forcing employers to accept their legal responsibilities. However, with a tightening labour market the likelihood is that strikes will increasingly be provoked by the aspiration of workers to achieve improvements in their wages and working conditions that are not embodied in the existing laws, labour contracts and collective agreements, as in the wave of strikes at the end of 2005 and in early 2006.

It will prove increasingly difficult for the authorities to settle such strikes by pressing employers to abide by their legal obligations. ${ }^{16}$ They will then face the alternative of continuing to press employers to accept the workers' demands, which will reinforce the tendency for workers to pursue their interests through strikes, or adopting repressive measures to suppress strikes, which will lead to political confrontations between workers and the workers' state. In either situation, the trade union as mediator risks being sandwiched between employers and workers and further losing credibility in the eyes of both (in the 2005-6 strikes many of the enterprise union leaders simply hid themselves away). A 
senior DOLISA official in HCMC told us that not only are trade unionists insufficiently protected from victimization by the employer, but also that sometimes workers threaten the trade union leader after a dispute and there is no adequate mechanism to protect union leaders from the workers.

The recent strike wave brought a divergence of opinion into the open as VGCL sought to confine the strikes within the rights-based framework by interpreting the workers to be demanding an increase in the legal minimum wage, blaming the government for its failure to anticipate the unrest by increasing the minimum wage in good time, and more generally blaming MOLISA for its failure adequately to monitor the implementation of labour legislation, while MOLISA insisted that wage increases should be negotiated by trade unions with management, not legislated by the government, so the strikes highlighted the weakness of VGCL organization in the workplace. This divergence indicates two possible directions for the development of industrial relations in Vietnam. On the one hand, VGCL is still committed to a rights-based industrial relations system, with the powers of the regional trade union organizations increased to enable them to participate directly in collective bargaining and conflict resolution, without giving any significant role to the workplace trade union organization. On the other hand, the government, led by MOLISA, is pressing for VGCL to take responsibility for negotiating the terms and conditions of employment directly with employers, rather than relying on the government to prescribe those terms and conditions. This implies a more active role and increased support for the workplace trade union organization. The proposed amendments to Chapter I4 of the Labour Code, distinguishing between procedures for the resolution of rights-based and interest-based disputes, seeks to paper over this disagreement.

The weakness of the system does not lie in the inadequacy of dispute resolution procedures, but in the absence of an institutional framework that can reduce the likelihood of such a breakdown arising in the first place. The underlying weakness of the system is the lack of an effective mechanism through which the inevitable conflict of interest between employers and employees can be reconciled through negotiation and the resulting compromise embodied in collective agreements binding on both sides. This systemic weakness is a reflection of the weakness of workplace trade unions and their failure to articulate the aspirations of their members. On the one hand, the majority of non-state enterprises do not have trade union organizations. On the other hand, where a trade union exists it is dependent upon management, if not integrated into management structures. VGCL recognizes the weakness of its primary organizations, but has done very little to address the problem. While formally the internal procedures of VGCL are very democratic, in practice its primary organizations are to only a very limited extent accountable to their members and so perform only a very weak representative role. Moreover, VGCL does not provide its primary organizations with the training and support that they require to become effective collective bargaining agents.

The priority for the development of a stable industrial relations system in 
Vietnam is therefore not the reinforcement of the legal framework by improving the clarity of legal regulation and the legal knowledge of employers and workers, which is the focus of Vietnamese discussion of the issue, but the strengthening of the substantive foundations of the system by strengthening the mechanisms that ensure the accountability of the trade union organization to its members and by providing workplace trade union officers with the skills and resources required to bargain effectively on behalf of their members.

\section{Notes}

I The present article complements an article by Chang-Hee Lee, recently published in this journal ('Transformation of Industrial Relations in East Asian Transition Economies: Review of Industrial relations changes in China and Viet Nam', Fournal of Industrial Relations 48(3), 2006), which provides a more balanced comparison of the two countries, with a particular emphasis on the development of tripartism, while the present article focuses on workplace industrial relations.

2 This article is based on published English-language sources; a two-week fieldwork trip to Vietnam in November 2004 and a report prepared in March 2006 by Do Quynh Chi on the first stage of fieldwork (Vietnam Research Team, 2006) for a project on 'Post-socialist trade unions, low pay and decent work', funded by the British ESRC under its Non-Governmental Public Action Programme (award RES-I 55-2 5-O07I). On the 2004 trip Simon Clarke, Chang-Hee Lee and Do Quynh Chi spent one week in Hanoi and one week in Ho Chi Minh City, interviewing trade union, employer and government representatives at national, city and district levels and spending half a day interviewing trade union and employer representatives in each of five enterprises in each city, covering the foreign-invested, domestic-private and equitized-state sectors (we did not visit any pure state enterprises), all with trade union organizations, but with a mix of enterprises with a good and a bad industrial relations record. Contrary to our expectations, we did not find any radical differences between the situations in the North and the South. We are very grateful to Jan Jung-Min Sunoo and Nguyen Binh of the ILO/Vietnam Industrial Relations Project, who answered many questions for us, and to all our informants in Vietnam.

3 Unless otherwise stated, figures are from Vietnam General Statistics Office data and other information from our own interviews.

4 On the other hand, since affiliates of sectoral unions tend to be SOEs, they are more likely to be under the supervision of an active Party organization.

5 Nor does MOLISA have an industrial relations department, responsibility for IR falling to the legal department. Proposals to set up a collective bargaining department in VGCL and an industrial relations unit in MOLISA are still under discussion.

6 A handbook being prepared by the ILO Industrial Relations Project is scheduled for publication in the middle of 2006.

7 According to MOLISA's strike research in 2006 only 20 percent of enterprises had collective agreements and over 90 percent of these were simply a replication of labour law regulations rather than the outcome of real negotiations.

8 Taiwanese and Korean employers interviewed after the 2006 strike wave reported that they now communicate directly with employees to identify their needs and complaints, rather than relying on the trade union, which they considered to be 'ineffective and indifferent to workers' interests'.

9 The one domestically owned private enterprise that we visited was similar to a joint 


\section{Clarke, Lee \&o Chi: Industrial Relations in Vietnam}

venture in that it had been created by gutting a state enterprise on the basis of overseas Vietnamese investment, with most of the management coming from the former state enterprise. The trade union president kept the owner in check.

Io A recent MOLISA survey of 437 enterprises around the country found that more than half, including half the FIEs, violated overtime regulations. An inspection of 28 enterprises in one district of HCMC found that half the workers were not insured (Tan, 2005). Following the 2006 strike wave, enterprise violations were widely publicized. For example, only two of 40 organizations inspected in Binh Duong IZ met all of the requirements of the Labour Laws. Only nine provided labour contracts for all workers, and four companies provided no contracts at all, both weakening the workers' protection and avoiding the payment of social insurance (Vietnamnet, 6 January 2006).

I I A study in 2002 interviewed a small number of workers in Taiwanese-owned factories in Vietnam and found that without a code of conduct legal violations are rife, that Nike effectively enforces its code of conduct in its subcontractors, but other contractors and regulators do so less effectively. Those workers who had not joined the union explained that 'it is controlled by the management, and those Vietnamese union cadres are utilized by Taiwanese to dominate workers' (Wang, 2002).

I 2 For a detailed account of strikes in Vietnam see Clarke (2006).

I3 Within the state-socialist system these laws were not so much juridical instruments as ethical ideals, a conception of the law that persists in Vietnam today. A senior MOLISA official described the Labour Code as 'what we would like to achieve, but not now', while a senior VGCL official similarly described the collective agreement as a statement of aspirations, while the individual contract is the basis of labour relations. The Communist Party dream is that 'by 2020, all aspects of social life will be regulated by laws and codes' ('Realising Resolutions of the Ninth Party Congress', Tap chi Cong san [Communist Review], 20 [I 5 October], 2004).

I4 'Strikes happen because trade unions are so weak at the workplace and they do not represent workers at the workplace. There has been no strike initiated by a trade union because workers do not trust trade unions at the workplace' (Senior VCCI official). Task force report: 'The role of trade union steering committee is not strong and passive. Trade union leaders have not shown their capacity and responsibility in protecting rights and interests of workers as well as guiding and organizing strike as regulated in labour law' (Hop, 2004: 4). 'Participants at a general meeting of the VGCL in Hanoi this month acknowledged that the local trade unions have not lived up to their responsibilities. Only $27.5 \%$ of a total of the over IO, IOO trade unions were judged to be active and effective in carrying out their duties ... The VGCL attributes many problems and legal violations to the ineffectiveness of the trade unions' (Lao Dong, cited in Vietnam Update, 24 June, 2002).

I5 Employers exchange information about the wages they pay and discuss any proposed increases with their neighbours. No doubt the various foreign employers' associations play a role in suppressing active competition in the labour market. One employer, discussing this exchange of information about wages, stressed that 'this is not a conspiracy to hold down wages, just co-ordination'. In the recent strike wave at the end of 2005 there was no evidence of co-ordination among employers to resist raising wages, instead they fell like dominoes, one after the other.

I6 One Korean manager revealed after the 2006 strike wave that his company had been advised that the strikes were illegal and the company should hold on for a few days for an official settlement rather than raising wages immediately. However, almost all companies chose to raise wages in order to stop the strikes. 


\section{References}

Chan, A. and Nörlund, I. (1998) 'Vietnamese and Chinese Labour Regimes: On the Road to Divergence', China fournal 40: I 73-97.

Chan, A. and Wang, Hong-Zen (2004) 'The Impact of the State on Workers' Conditions: Comparing Taiwanese Factories in China and Vietnam', Pacific Affairs 77(4): 629-46.

Clarke, S. (2006) 'The Changing Character of Strikes in Vietnam', Post-Communist Economies, May.

Dixon, C. (2000) 'State versus Capital: The Regulation of the Vietnamese Foreign Sector', Singapore Fournal of Tropical Geography 2 I (3): 279-94.

Fair Labor Association (2004) Annual Public Report: Freedom of Association in Vietnam, http:// www.fairlabor.org/2004report/freedom/vietnam.html (consulted Oct. 2004).

Hop, Thach Bich (2004) Report of High-Level Task Force on Labour Dispute and Strike (in Dong Nai, Binh Duong and Ho Chi Minh City), Hanoi, 5 May.

Lan, Dang (1995) 'Trade Union Problems in Vietnam', Lao Dong, I June, http://www.fva. org/o795/trade.html (consulted Jan. 2005).

Li, Qi, Taylor, B. and Frost, S. (2003) 'Labour Relations and Regulation in Vietnam: Theory and Practice', Working Paper No. 53, September. Hong Kong: Southeast Asia Research Centre, City University.

Socialist Republic of Vietnam (I 990) 'Law on Trade Unions: Unofficial English Translation', http://www.osh.netnam.vn/luatphap/ENG_cd.htm (consulted Nov. 2004).

Socialist Republic of Vietnam (I994) 'Labour Code of Socialist Republic of Vietnam', http:// www.ilo.org/dyn/natlex/docs/WEBTEXT/38229/64933/E94VNMor.htm (consulted Nov. 2004).

Socialist Republic of Vietnam (2002) 'Labour Code of Socialist Republic of Vietnam', http://www.global-standards.com/Resources/VNLaborCoder994-2002.pdf (consulted Jan. 2005).

Tan, Le Duc (2005) 'Grounds for Dispute', Vietnam Economic Times, I32 (I February), http://www.vneconomy.com.vn/vet/?param=info\&name=Business $\% 2$ oreport\&id=53 I 4 (consulted March 05).

Vietnam Research Team (2006) The Policy and Practice of the Vietnamese Government and Trade Unions in Relation to Low Wages and Poor Working Conditions. Hanoi: NGPA Project Report accessed I6 June 2006 http://go.warwick.ac.uk/Russia/ngpa/vnrepi.doc

Wang, Hong-Zen (2002) 'A New Paradigm or an Old Trick?: The Effect of Corporate Codes of Conduct in Taiwanese-owned Factories in Vietnam', paper presented at the Society for the Advancement of Socio-Economics 2002 Conference, University of Minnesota Minneapolis, 27-30 June.

Wang, Hong-Zen (2005) 'Asian Transnational Corporations and Labor Rights: Vietnamese Trade Unions in Taiwan-invested Companies', Fournal of Business Ethics 56(I): 43-53.

World Bank (2004a) Vietnam: Key Economic Indicators, November, http://siteresources. worldbank.org/INTVIETNAM/Resources/Vaitnam-Indicators-Novo4.pdf (consulted Jan. 2005).

World Bank (2004b): Vietnam at a Glance, I6 September,http://www.worldbank.org/data/ countrydata/aag/vnm_aag.pdf (consulted Jan. 2005).

Zhu, Y. (2002) 'Economic Reform and Human Resource Management in Vietnam', Asia Pacific Business Review 8(3): I I 5-35.

Zhu, Y. and Fahey, S. (1999) 'The Impact of Economic Reform on Industrial Labour Relations in China and Vietnam', Post-Communist Economies I I(2): I 73-92.

Zhu, Y. and Fahey, S. (2000) 'The Challenges and Opportunities for the Trade Union Movement in the Transition Era: Two Socialist Market Economies - China and Vietnam', Asia Pacific Business Review, 6 (3-4): 282-99. 